\title{
Heterogeneous ice nucleation of viscous secondary organic aerosol produced from ozonolysis of $\alpha$-pinene
}

\author{
Karoliina Ignatius $^{1}$, Thomas B. Kristensen ${ }^{1}$, Emma Järvinen $^{2}$, Leonid Nichman ${ }^{3}$, Claudia Fuchs $^{4}$, Hamish Gordon $^{5}$, \\ Paul Herenz $^{1}$, Christopher R. Hoyle ${ }^{4,6}$, Jonathan Duplissy ${ }^{7}$, Sarvesh Garimella ${ }^{8}$, Antonio Dias ${ }^{5}$, Carla Frege ${ }^{4}$, \\ Niko Höppel $^{2}$, Jasmin Tröstt ${ }^{4}$, Robert Wagner ${ }^{7}$, Chao Yan ${ }^{7}$, Antonio Amorim ${ }^{9}$, Urs Baltensperger ${ }^{4}$, \\ Joachim Curtius $^{10}$, Neil M. Donahue ${ }^{11}$, Martin W. Gallagher ${ }^{3}$, Jasper Kirkby ${ }^{5,10}$, Markku Kulmala ${ }^{7}$, \\ Ottmar Möhler ${ }^{2}$, Harald Saathoff ${ }^{2}$, Martin Schnaiter ${ }^{2}$, Antonio Tomé $^{12}$, Annele Virtanen ${ }^{13}$, Douglas Worsnop ${ }^{14}$, and \\ Frank Stratmann ${ }^{1}$ \\ ${ }^{1}$ Leibniz Institute for Tropospheric Research (TROPOS), 04318 Leipzig, Germany \\ ${ }^{2}$ Institute of Meteorology and Climate Research - Atmospheric Aerosol Research, Karlsruhe Institute of Technology, \\ Karlsruhe, Germany \\ ${ }^{3}$ School of Earth, Atmospheric and Environmental Sciences, University of Manchester, Manchester, M13 9PL, UK \\ ${ }^{4}$ Laboratory of Atmospheric Chemistry, Paul Scherrer Institute, Villigen, Switzerland \\ ${ }^{5}$ CERN, 1211 Geneva, Switzerland \\ ${ }^{6}$ WSL Institute for Snow and Avalanche Research SLF Davos, Davos, Switzerland \\ ${ }^{7}$ Department of Physics, P.O. Box 64, 00014 University of Helsinki, Helsinki, Finland \\ ${ }^{8}$ Massachusetts Institute of Technology, Cambridge, MA, USA \\ ${ }^{9}$ SIM/CENTRA and F. Ciencias, Universidade de Lisboa, Lisbon, Portugal \\ ${ }^{10}$ Goethe-University of Frankfurt, Institute for Atmospheric and Environmental Sciences, Altenhöferallee 1, \\ 60438 Frankfurt am Main, Germany \\ ${ }^{11}$ Center for Atmospheric Particle Studies, Carnegie Mellon University, Pittsburgh, PA 15213, USA \\ ${ }^{12}$ SIM/IDL, Universidade da Beira Interior, Covilhã, Portugal \\ ${ }^{13}$ Department of Applied Physics, University of Eastern Finland, Kuopio, Finland \\ ${ }^{14}$ Aerodyne Research, Inc., Billerica, MA 08121, USA \\ Correspondence to: Karoliina Ignatius (ignatius@ tropos.de)
}

Received: 7 November 2015 - Published in Atmos. Chem. Phys. Discuss.: 18 December 2015

Revised: 16 April 2016 - Accepted: 9 May 2016 - Published: 27 May 2016

\begin{abstract}
There are strong indications that particles containing secondary organic aerosol (SOA) exhibit amorphous solid or semi-solid phase states in the atmosphere. This may facilitate heterogeneous ice nucleation and thus influence cloud properties. However, experimental ice nucleation studies of biogenic SOA are scarce. Here, we investigated the ice nucleation ability of viscous SOA particles.

The SOA particles were produced from the ozone initiated oxidation of $\alpha$-pinene in an aerosol chamber at temperatures in the range from -38 to $-10^{\circ} \mathrm{C}$ at $5-15 \%$ relative humidity with respect to water to ensure their formation in a highly viscous phase state, i.e. semi-solid or glassy. The ice nucleation ability of SOA particles with different sizes was
\end{abstract}

investigated with a new continuous flow diffusion chamber. For the first time, we observed heterogeneous ice nucleation of viscous $\alpha$-pinene SOA for ice saturation ratios between 1.3 and 1.4 significantly below the homogeneous freezing limit. The maximum frozen fractions found at temperatures between -39.0 and $-37.2{ }^{\circ} \mathrm{C}$ ranged from 6 to $20 \%$ and did not depend on the particle surface area. Global modelling of monoterpene SOA particles suggests that viscous biogenic SOA particles are indeed present in regions where cirrus cloud formation takes place. Hence, they could make up an important contribution to the global ice nucleating particle budget. 


\section{Introduction}

Atmospheric aerosol particles are known to influence the Earth's radiative balance and climate directly by reflecting and absorbing sunlight, and indirectly through their influence on clouds, e.g. when the particles act as cloud condensation nuclei $(\mathrm{CCN})$ and/or ice nucleating particles (INPs) (Yu et al., 2006). Determining the role of aerosols in ice nucleation is particularly complex because of different pathways through which ice forms in the atmosphere. Ice nucleation can be either homogeneous - freezing of pure water or solute droplets - or heterogeneous, in which case ice formation is induced by foreign surfaces such as mineral dust or bacteria (Pruppacher and Klett, 1997). Homogeneous ice nucleation requires temperatures below approximately $-37^{\circ} \mathrm{C}$ and high supersaturations, typically ice saturation ratios $S_{\text {ice }}$ of 1.4 or larger (Koop et al., 2000), and can contribute to cirrus cloud formation.

Heterogeneous ice nucleation is considered to be an important pathway for ice formation in the troposphere, especially in mixed-phase clouds (Hoose and Möhler, 2012; Murray et al., 2012), but also in cirrus clouds (Krämer et al., 2009; Cziczo et al., 2013). Immersion freezing of aerosol particles activated into supercooled cloud droplets is the most important process for primary ice formation down to temperatures of around $-35^{\circ} \mathrm{C}$. Deposition ice nucleation, on the other hand, is more relevant at lower temperatures, and the typical INPs inducing deposition nucleation are different mineral dusts, such as clay minerals and Saharan dust (DeMott et al., 2003; Möhler et al., 2006; Welti et al., 2009; Hoose and Möhler, 2012). DeMott et al. (2010) found that only about 1 in $10^{5}$ or $10^{6}$ atmospheric aerosol particles can act as an INP. In heterogeneous ice nucleation, the surface area of the seed particles typically plays an important role, so that larger particles tend to be more efficient INPs (Connolly et al., 2009; Welti et al., 2009).

Secondary organic aerosol (SOA) can exist in a semi-solid, amorphous state in the atmosphere (Zobrist et al., 2008; Virtanen et al., 2010), and it has been suggested that amorphous SOA particles could play a role in ice nucleation (Murray et al., 2010). SOA is produced in the atmosphere from oxidation and subsequent condensation of volatile organic compounds (VOCs) (Hallquist et al., 2009) of which the majority are biogenic (Guenther et al., 1995; Jimenez et al., 2009). SOA is very abundant especially in the lower troposphere where it comprises around 30 to $70 \%$ of the submicron particulate mass (Kanakidou et al., 2005). Monoterpenes such as $\alpha$-pinene are one of the most common biogenic SOA precursors, especially in boreal forest regions (Laaksonen et al., 2008). Other precursors include e.g. limonene in Australian Eucalyptus forests (Suni et al., 2007) and isoprene (Guenther et al., 2006).

The phase state of SOA depends on temperature and relative humidity (RH) (Zobrist et al., 2008) and has recently received more attention, since it determines the impact of SOA on cloud formation and therefore climate (Renbaum-Wolff et al., 2013). Depending on particle hygroscopicity, the viscosity of SOA is RH dependent; e.g. SOA produced from ozonolysis of $\alpha$-pinene is known to take up water at high relative humidities (Pajunoja et al., 2015). Since humidity conditions vary significantly in the troposphere, SOA particles may exhibit many different phase states during their lifetime in the atmosphere. Ice particle residuals from cirrus clouds sampled in situ were rich in oxidized organic matter (Froyd et al., 2009, 2010), which indicates that viscous or glassy organic particles may also have acted as INPs during cirrus formation. Modelling studies suggest that viscous SOA could be an important INP especially at low temperatures and low humidities, i.e. in the cirrus regime (Murray et al., 2010; Koop et al., 2011; Adler et al., 2013; Berkemeier et al., 2014; Price et al., 2015). Furthermore, experimental studies of the ice nucleation ability of viscous SOA proxies support the model findings. In chamber expansion studies, glassy citric acid, raffinose and levoglucosan particles nucleated ice heterogeneously at temperatures between -80 and $-50^{\circ} \mathrm{C}$ (Murray et al., 2010; Wagner et al., 2012; Wilson et al., 2012). Sucrose, glucose and citric acid particles were found to be very efficient INPs in the deposition mode at temperatures between -70 and $-40{ }^{\circ} \mathrm{C}$ since they nucleated ice at low ice saturation ratios $\left(S_{\text {ice }}=1.1\right)$ (Baustian et al., 2013). Simulated SOA from aqueous phase reactions of methylglyoxal and methylamine have also shown ice nucleation potential in the deposition mode (Schill et al., 2014).

Amorphous SOA particles generated via gas-phase oxidation of naphthalene with $\mathrm{OH}$ radicals are considered relatively efficient INPs (Wang et al., 2012). Ladino et al. (2014) and Möhler et al. (2008) reported SOA produced from ozonolysis of $\alpha$-pinene to be a poor or inefficient INP. In both studies, however, the phase state of SOA particles was not investigated experimentally, and the particles were produced at room temperature in a separate aerosol preparation chamber from which a fraction of them was transferred to the actual ice nucleation chamber. Thus, it is likely that these particles never featured a high viscosity, liquefied easily and the resulting droplets froze homogeneously. Ladino et al. (2014) also pointed out that precooling of the $\alpha$-pinene SOA particles made them slightly better INPs, possibly due to a change in viscosity.

Here, we report first observations of heterogeneous ice nucleation of laboratory-generated viscous, semi-solid $\alpha$ pinene SOA. The phase state of the SOA particles was detected via the depolarization signal of light scattered from the particles, using a novel optical method described in detail in a companion study (Järvinen et al., 2016). A new portable INP counter was used to sample the SOA particles and measure their ice nucleation efficiency. Finally, a global model was applied to investigate to what extent viscous SOA particles could contribute to the global INP budget. 


\section{Methods}

\subsection{Experimental setup: chamber experiments}

The SOA particles were produced in the CLOUD (Cosmics Leaving Outdoor Droplets) chamber at CERN (Duplissy et al., 2010, 2016; Kirkby et al., 2011; Hoyle et al., 2016) during the CLOUD9 campaign between 25 October and 3 November 2014. SOA particles were produced from ozonolysis of $\alpha$-pinene at low relative humidity with respect to water $\left(\mathrm{RH}_{\mathrm{w}}\right)(5-15 \%)$ at four different temperatures, $-10,-20,-30$ and $-38^{\circ} \mathrm{C}$, which are relevant for the free troposphere. $\alpha$-pinene and ozone were introduced to the chamber at the rate of 10 and $1000 \mathrm{~mL} \mathrm{~min}^{-1}$ (respectively) over a time period of a few minutes. UV lights (Philips TUV $130 \mathrm{~W}$ XPT lamp) were on during this time, resulting in the photolysis of $\mathrm{O}_{3}$ and $\mathrm{OH}$ formation. High number concentrations of particles $\left(>10^{5} \mathrm{~cm}^{-3}\right.$ ) quickly formed a monomodal size distribution which grew to approximately $100 \mathrm{~nm}$ in diameter. During the particle growth, $\alpha$-pinene and ozone were continually introduced into the chamber. The particles were grown to approximately $600-800 \mathrm{~nm}$ in diameter in order to follow the size-dependence of their optical properties. The depolarization ratio was measured, and based on the determined depolarization of the backscattered light, it was determined whether the particles were aspherical and thus (highly) viscous (detectable depolarization). Then the $\mathrm{RH}_{\mathrm{w}}$ was slowly increased for the optical detection of the phase transition of the particles from higher to lower viscosity or liquid phase, i.e. the point where the depolarization ratio decreased significantly to a level of spherical particles. The transition $\mathrm{RH}_{\mathrm{w}}$ increased with the decreasing temperature, from $35 \%$ at $-10^{\circ} \mathrm{C}$ to $80 \%$ at $-38^{\circ} \mathrm{C}$. Further experimental details are explained in Järvinen et al. (2016). The ice nucleation ability of the SOA particles was measured by sampling them from the CLOUD chamber at different growth stages in order to examine particles with different sizes. In Table 1 the particle sizes and number concentrations for the different experiments are included together with information about the chamber temperature and humidity conditions. The particle number size distributions were measured with several Scanning Mobility Particle Sizer (SMPS) systems $(20-800 \mathrm{~nm})$, and optically with an Ultra High Sensitivity Aerosol Spectrometer (UHSAS, Droplet Measurement Technologies, Inc.) in the range from $60 \mathrm{~nm}$ to $1 \mu \mathrm{m}$. In addition, an Aerodyne high-resolution time-of-flight aerosol mass spectrometer (HR-ToF AMS) was used to determine the chemical composition of the SOA particles.

\subsection{Ice nucleation instrumentation}

We used the Spectrometer for Ice Nuclei (SPIN) to measure the ice nucleation efficiency of the SOA particles generated in the CLOUD chamber. SPIN is a new, commercially available portable INP counter manufactured by Droplet Mea- surement Technologies, Inc. The final version and the performance of SPIN are described in more detail by Garimella et al. (2016). The main difference between the version of SPIN used in this study and the final version is related to better temperature control of the final version.

SPIN is a continuous flow diffusion chamber with parallel plate geometry adapted from the design of the Portable Ice Nucleation Chamber PINC (Chou et al., 2011) and the Zurich Ice Nucleation Chamber ZINC (Stetzer et al., 2008). The aerosol sample flow is set to $1 \mathrm{~L} \mathrm{~min}^{-1}$ surrounded by a sheath flow of $10 \mathrm{Lmin}^{-1}$ flowing through a chamber where a supersaturation of water vapour with respect to ice is obtained by keeping two ice covered walls at different temperatures below $0^{\circ} \mathrm{C}$. The residence time in the upper part of the chamber where ice nucleation may take place is approximately $10 \mathrm{~s}$. The aerosol sample and sheath air flows are then exposed to an isothermal, separately temperaturecontrolled evaporation section where the unfrozen droplets evaporate while the ice particles are retained, prior to particle detection with a linear polarization optical particle counter (OPC). The OPC laser is polarized, and the intensity of the backscattered light perpendicular to the incident polarization and the intensity of the backscattered polarized light are measured on a particle by particle basis. The polarizationequivalent ratio between the two intensities provides information about the phase state of the particles. The size measurements of the SPIN OPC were calibrated using two sizes of polystyrene latex spheres (PSL), 0.9 and $2 \mu \mathrm{m}$, and glass beads of 5 and $8 \mu \mathrm{m}$. A power law fit was applied to the calibration data, and the full size distribution was extrapolated from the fit. The detection efficiency of the OPC was investigated with different sizes of monodisperse PSL spheres in the range from $300 \mathrm{~nm}$ to $1.0 \mu \mathrm{m}$. The lower detection limit of the SPIN OPC was approximately $400 \mathrm{~nm}$, with a detection efficiency of $\sim 50 \%$. For particles larger than $700 \mathrm{~nm}$, the detection efficiency was close to $100 \%$. For particle sizes between 550 and $600 \mathrm{~nm}$, the detection efficiency was approximately $80 \%$. This allows the SPIN OPC to detect also the seed aerosol particles if they are large enough. Typical backgrounds during the experiments with viscous SOA particles were of the order of 10-20 particles per litre. The frozen fraction lower limit of detection was typically of the order of $1 \times 10^{-4}$.

The temperature of the aerosol sample flow and the supersaturation with respect to ice are modelled based on the continuous measurement of the wall temperatures. Due to a temperature gradient between the walls, there is a buoyancy effect to the air mass inside the chamber, pushing the sample flow closer to the colder wall. This effect has been taken into account in the 1-D modelling and calculations of the sample temperature and humidity which are done according to Rogers (1988). A condensation particle counter (CPC3720 , TSI) was run parallel to SPIN during half of the runs, when the sample particle size was smaller than $500 \mathrm{~nm}$. SPIN was operated by keeping the colder wall at constant temper- 
Table 1. The conditions for the ice nucleation experiments with viscous $\alpha$-pinene SOA. The columns from left to right list the dates when the experiment was carried out, the average temperature in the CLOUD chamber during the particle sampling with the INP counter SPIN, the average relative humidity with respect to water $\mathrm{RH}_{\mathrm{W}}$ in the CLOUD chamber, mean particle mobility diameters and the sampled particle number concentrations measured by the SPIN optical particle counter (OPC) and a condensation particle counter (CPC). For each experiment, 1 to 4 ice nucleation onset measurements were performed. The CPC was operated parallel to SPIN during half of the runs. For the runs without CPC number concentrations, frozen fractions could be estimated from the SPIN OPC particle number concentrations and size distributions.

\begin{tabular}{rrrrrr}
\hline Date & $\begin{array}{r}\text { Chamber } T \\
\left({ }^{\circ} \mathrm{C}\right)\end{array}$ & $\begin{array}{r}\text { Chamber } \mathrm{RH}_{\mathrm{w}} \\
(\%)\end{array}$ & $\begin{array}{r}\text { Particle diameter } \\
(\mathrm{nm})\end{array}$ & $\begin{array}{r}\text { SPIN OPC conc. } \\
\left(\mathrm{cm}^{-3}\right)\end{array}$ & $\begin{array}{r}\text { CPC conc. } \\
\left(\mathrm{cm}^{-3}\right)\end{array}$ \\
\hline 25 Oct & -10 & 12 & 800 & 200 & - \\
26 Oct & -20 & 10 & 550,600 & $150-600$ & - \\
27 Oct & -20 & 10 & 800 & 150 & 150 \\
28 Oct & -30 & 10 & 320,630 & - & 490 \\
29 Oct & -38 & 10 & 330 & - & 310 \\
3 Nov & -38 & 60 & 120 & - & 130 \\
\hline
\end{tabular}

ature at its lower limit and ramping up the temperature of the warm wall, thus raising the sample temperature from approximately -43 to $-35^{\circ} \mathrm{C}$ and ice saturation ratio $S_{\text {ice }}$ from 1 to approximately $1.45-1.5$ inside the instrument. In order to minimize fluctuations of the wall temperatures, the regime of operation for the current study was limited to a minimum temperature of $-43^{\circ} \mathrm{C}$ for the colder wall.

SPIN sampled the SOA particles from the CLOUD chamber through a $1.5 \mathrm{~m}$ long, quarter inch stainless steel tubing, in which the residence time was approximately $2 \mathrm{~s}$. As the concentrations of the SOA particles in the CLOUD chamber typically exceeded $10000 \mathrm{~cm}^{-3}$, a dilution system partly filtering away aerosol particles was used to dilute the sample so that the particle number concentrations entering SPIN would stay under $1000 \mathrm{~cm}^{-3}$ in order to avoid saturating the optical detector. The stainless steel tubing together with the dilution system was insulated, but the temperature of the sample was not continually measured at the SPIN inlet, and it is possible that the temperature in the sampling tube was higher than in the CLOUD chamber.

\subsection{Instrument performance evaluation by homogeneous freezing of highly diluted ammonium sulphate droplets}

Homogeneous freezing of highly diluted ammonium sulphate droplets was used to evaluate the performance of the SPIN chamber and the optical detector. Ammonium sulphate particles were generated from a 1.0 mass $\%$ solution with a medical nebulizer, dried in a diffusion dryer and then sizeselected by a Differential Mobility Analyser (DMA). Mean mobility diameters of 200 and $500 \mathrm{~nm}$ were chosen, and a CPC (CPC-3010, TSI) was run in parallel to measure the total particle concentration.

The freezing experiments were designed in the following way: first a supersaturation with respect to ice and water was created inside SPIN by diverging the wall temperatures in order to obtain the necessary temperature gradient, while keep- ing the sample temperature below $-37^{\circ} \mathrm{C}$, which is the upper threshold temperature for homogeneous freezing in the atmosphere (Pruppacher and Klett, 1997). After water (super) saturation was achieved and ice formation observed, both walls were heated at the same rate in order to increase the sample temperature but keep the water supersaturation, leading to the disappearance of ice. The temperature of the evaporation section walls was kept constant at $-35^{\circ} \mathrm{C}$.

An example of such an experiment is displayed in Fig. 1. In the upper left panel, the SPIN wall and sample (lamina) temperatures, as well as the relative humidity with respect to liquid water are plotted as a function of time. The upper right panel shows the particle number concentrations in different size bins from the same experiment. At subsaturated conditions with respect to liquid water only the $500 \mathrm{~nm}$ seed aerosol particles are observed. When water saturation is reached shortly after $14.3 \mathrm{~h}$, most of the seeds activate to droplets which then freeze, forming a distinct mode with sizes around $5 \mu \mathrm{m}$. As the sample temperature is increased, the ice mode vanishes at approximately $14.4 \mathrm{~h}$ and a mode consisting of liquid droplets with sizes of $\sim 2-3 \mu \mathrm{m}$ remains.

In the lower three panels of Fig. 1, the size distributions measured by the SPIN OPC from the same experiment are shown. Panel (a) shows the dry $500 \mathrm{~nm}$ seed aerosol particles that have not yet activated. Panel (b) illustrates the situation when most of the ammonium sulphate particles have activated into droplets and frozen. Panel (c) depicts the seed aerosol and liquid, highly diluted ammonium sulphate droplets at water supersaturation at temperatures above the homogeneous freezing point. All the data are normalized with respect to total particle counts from the OPC. The polarization-equivalent ratios $(S / P$ ratios) from the OPC are also different for ice crystals and liquid droplets: for ice, $S / P$ ratios vary between 0.5 and 0.6 , whereas for liquid droplets the ratios are significantly smaller, between 0.1 and 0.2 . This further confirms that the distinct modes in the size distributions correspond to different phase states, and the size distributions can also be used to define ice nucleation onset points. 

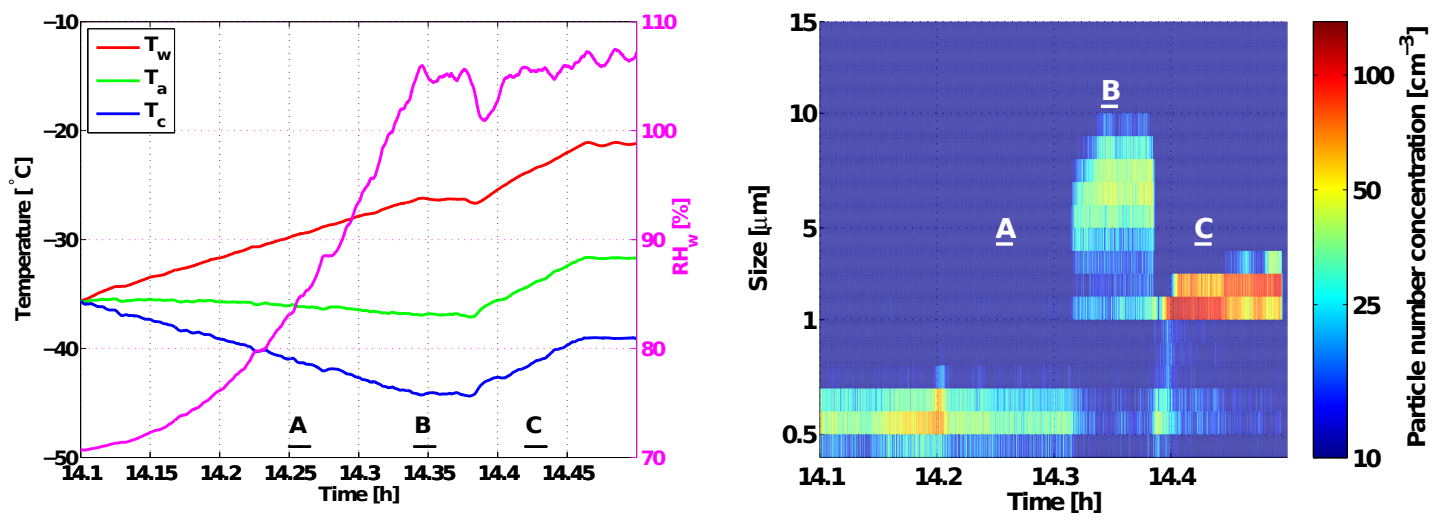

(a)

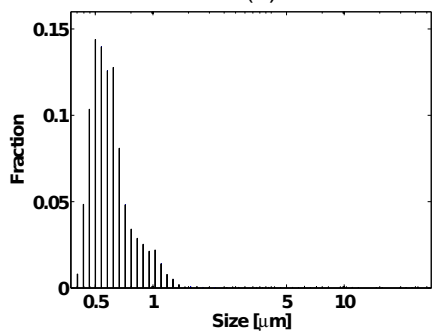

(b)
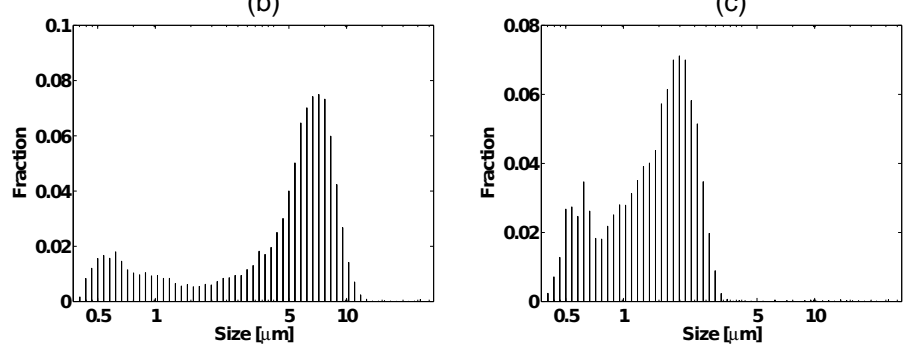

(a)

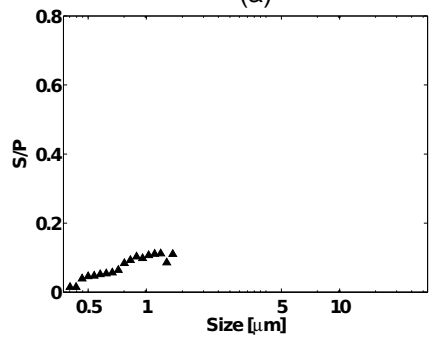

(b)
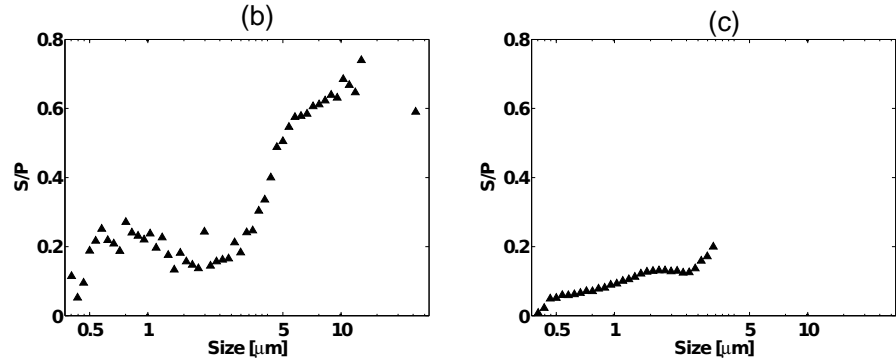

Figure 1. Homogeneous freezing of highly diluted ammonium sulphate droplets. In the top left panel, the SPIN cold and warm wall ( $T_{\mathrm{C}}$ and $\left.T_{\mathrm{W}}\right)$ and sample (lamina) temperatures $\left(T_{\mathrm{a}}\right)$, as well as the relative humidity with respect to liquid water $\left(\mathrm{RH}_{\mathrm{W}}\right)$ are plotted as a function of time. The top right panel shows the particle number concentrations in different size bins from the same experiment. Bars A, B, C in the top panels mark the time intervals from which the normalized SPIN OPC particle number size distributions and the median values of the polarization-equivalent $S / P$ ratios are shown in the corresponding lower panels. In (a) seed particles, in (b) seed and ice particles, in (c) seed particles and liquid droplets. The size distributions and $S / P$ ratios are averaged over $54 \mathrm{~s}$, and correspond to the following times in the upper panels: (a) $14.25-14.265 \mathrm{~h}$, (b) $14.34-14.355 \mathrm{~h}$, (c) $14.42-14.435 \mathrm{~h}$.

The ice nucleation onsets in these homogeneous freezing experiments were obtained in the following way. In Fig. 1, we use the transition from regime $\mathrm{B}$ to regime $\mathrm{C}$, not from regime $\mathrm{A}$ to regime $\mathrm{B}$, to obtain the ice nucleation onset temperature and ice saturation ratio. Due to the risk of cold pockets forming during active wall cooling, we scan the aerosol sample temperature upwards until the observed ice crystal mode vanishes and only liquid droplets remain. This temperature, at which a certain fraction (e.g. $10 \%$ ) of ice remains, is considered the ice nucleation onset. Although the ice nucleation onset here is actually ice offset, the conditions correspond to the ice nucleation onset conditions.

The homogeneous freezing temperatures for a frozen fraction of $10 \%$ are shown in Fig. 2. The homogeneous freezing temperatures are all found in the range from -37.9 to $-36.6^{\circ} \mathrm{C}$, with an average value of $-37.3^{\circ} \mathrm{C}$. The variation in $S_{\text {ice }}$ results from using slightly different temperature gradients to introduce a supersaturation with respect to water inside SPIN. Based on classical nucleation theory and the parameterization of homogeneous nucleation rates of water presented by Ickes et al. (2015), a frozen fraction of $10 \%$ can be expected for a temperature in the range from about -38.2 to $-37.6^{\circ} \mathrm{C}$. Uncertainties and variations in the residence time and the sizes of droplets formed inside SPIN result in the uncertainty in the expected homogeneous freezing temperature. Hence, the homogeneous freezing temperatures reported in Fig. 2 are within the range or slightly higher than what could be expected from theory. However, with a temperature difference between the SPIN chamber walls close to $20^{\circ} \mathrm{C}$, according to model simulations, the aerosol sample 


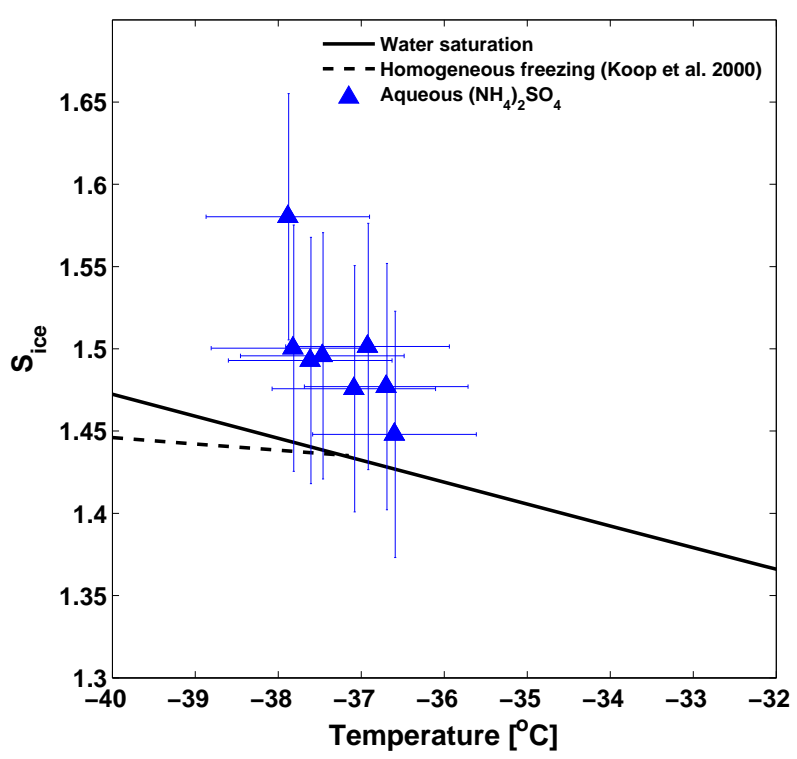

Figure 2. Homogeneous freezing temperatures of highly diluted ammonium sulphate droplets measured with SPIN. The frozen fraction here is $10 \%$. The uncertainties in temperature and ice saturation ratio shown here correspond to the $95 \%$ confidence interval calculated from the statistical standard deviation. The homogeneous freezing line from Koop et al. (2000) is calculated for $500 \mathrm{~nm}$ particles.

temperature range is approximately $\pm 0.4{ }^{\circ} \mathrm{C}$ with respect to the average temperatures presented in Fig. 2. Roughly half of the droplets formed inside SPIN will thus be exposed to temperatures down to $\sim 0.4^{\circ} \mathrm{C}$ below the average aerosol sample temperature. It would be expected that $>10 \%$ of the droplets formed inside SPIN are exposed to temperatures $>0.3^{\circ} \mathrm{C}$ below the reported average aerosol sample temperatures, which can explain most of the gap between the reported average aerosol temperatures and the theoretical homogeneous freezing temperature.

The freezing point depression caused by ammonium sulphate in the water droplets was calculated using the following formula:

$\Delta T=i M \times 1.86$,

where $i$ is the van't Hoff factor of the solute, $M$ is the molar concentration of the solution, and $1.86 \mathrm{KM}^{-1}$ is the freezing point depression for an ideal solution (Seinfeld and Pandis, 2006). For ammonium sulphate, $i=2.04$ (Wu et al., 2011). The droplet diameter here was estimated to be $3 \mu \mathrm{m}$. For $200 \mathrm{~nm}$ ammonium sulphate particles, this solute effect is negligible $\left(\Delta T=0.015^{\circ} \mathrm{C}\right)$; for $500 \mathrm{~nm}$ particles the freezing point depression is $0.24^{\circ} \mathrm{C}$, which is still within the uncertainty range of the aerosol sample temperature inside SPIN. Thus, we can conclude that the droplets were dilute enough so that the presence of ammonium sulphate did not significantly influence the freezing temperature.
With all the uncertainties considered, the correspondence between theory and experimentally obtained homogeneous freezing temperatures with SPIN is good, with a systematic tendency of the experimental average aerosol temperatures being slightly too high $\left(\lesssim 0.5^{\circ} \mathrm{C}\right)$. This off-set is likely to be due to occasional locally slightly colder chamber wall sections in between thermocouples relative to the temperature set-points. Based on the results presented in Fig. 2 it can be concluded that the aerosol sample conditions inside SPIN can be reproduced with good accuracy between different experiments, and the inferred aerosol sample conditions correspond well to what can be expected from theory. The standard deviation of the experimentally determined homogeneous freezing temperatures for $10 \%$ frozen fractions is $0.50{ }^{\circ} \mathrm{C}$. This variation can be considered to reflect the experimental random errors on the average aerosol sample temperature for the instrument for these operation conditions.

\section{Results and discussion}

Here we present results from heterogeneous ice nucleation measurements, on viscous $\alpha$-pinene SOA, obtained with SPIN. First, we show size distributions in order to demonstrate how we distinguish between unactivated seed aerosol, ice crystals and liquid droplets. Then, frozen fractions and ice activation conditions are presented, followed by a discussion about the possible freezing mechanisms and a comparison to literature data. Atmospheric implications of the results will be discussed at the end of the section.

\subsection{Size distributions}

Figure 3 shows results of a typical heterogeneous ice nucleation experiment with viscous SOA particles; this example is from 26 October 2014. Analogous to Fig. 1, the middle three panels show two particle number size distributions observed during subsaturated conditions with respect to liquid water, and a size distribution from an experiment, when the RH with respect to liquid water was greater than $100 \%$. The leftmost panel (a) shows the $550 \mathrm{~nm}$ seed aerosol and the middle panel (b) depicts the seeds and ice (a size mode around $5 \mu \mathrm{m}$ ) at water subsaturated conditions. A prominent droplet mode can be seen in the third panel (c), when the $\mathrm{RH}_{\mathrm{w}}$ was greater than $100 \%$, and it is possible that the SOA particles liquefied and froze homogeneously, as we have observed homogeneous freezing of diluted ammonium sulphate droplets at similar conditions. The different possible freezing mechanisms will be discussed in Sect. 3.4. The droplet mode in panel (c) likely consists of frozen droplets that have not grown very much due to potential activation close to the evaporation section of SPIN. This could also explain the slightly higher $S / P$ ratios (0.3) compared to the $S / P$ ratios of $0.1-0.2$ for the liquid droplets in Fig. 1c. 


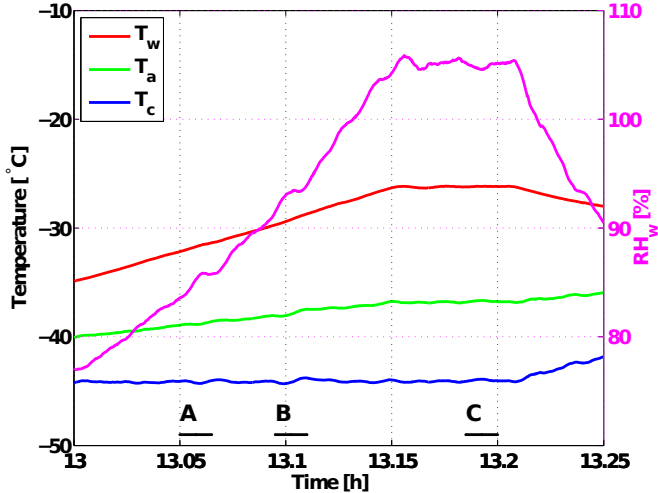

(a)

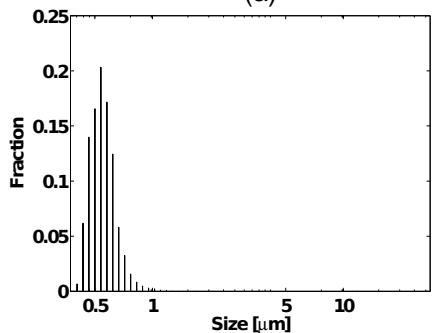

(a)

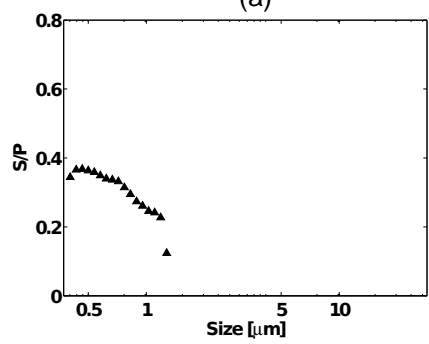

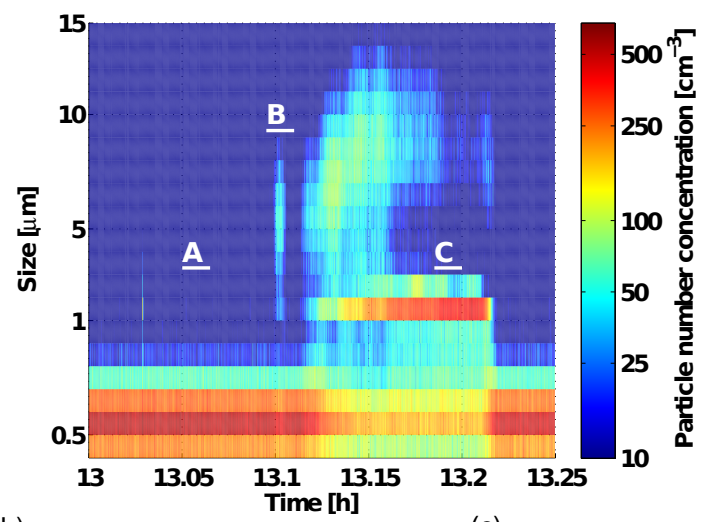

(c)

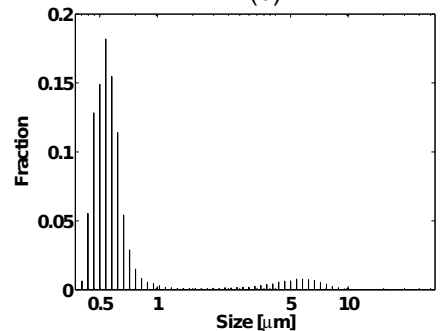

(b)

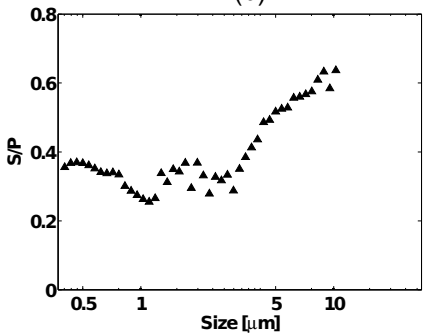

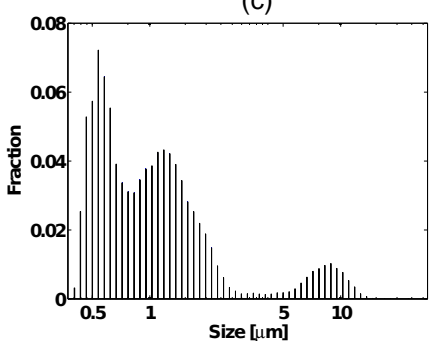

(c)

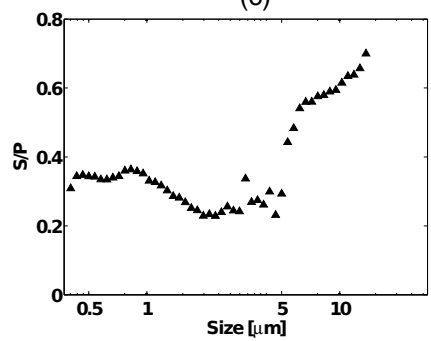

Figure 3. Heterogeneous ice nucleation of viscous $\alpha$-pinene SOA particles from 26 October 2014. Analogously to Fig. 1, the top left panel shows the SPIN wall and lamina temperatures and the $\mathrm{RH}_{\mathrm{W}}$ as a function of time, and the top right panel the particle number concentrations in different size bins. Also here, bars A, B, C in the upper panels correspond to the time intervals from which the normalized SPIN OPC particle number size distributions and median values of polarization-equivalent $S / P$ ratios are shown in the lower panels. Panel (a) shows the $550 \mathrm{~nm}$ seed aerosol and panel (b) depicts seeds and ice crystals at water subsaturated conditions. A prominent (frozen) droplet mode can be seen in panel (c), when freezing was observed at water supersaturation. The size distributions are averaged over $54 \mathrm{~s}$ and correspond to the following times in the upper panels: (a) $13.05-13.065 \mathrm{~h}$, (b) $13.095-13.11 \mathrm{~h}$, (c) $13.185-13.2 \mathrm{~h}$.

\subsection{Frozen fractions}

The fraction of particles activated as ice crystals was defined as the number of particles larger than the minimum between the seed aerosol and ice crystal modes, or between the liquid droplet and ice modes, divided by the total number of particles. In the case of SOA particles, this threshold size was $3 \mu \mathrm{m}$. It cannot be ruled out, however, that there is some size overlap between ice crystals and liquid droplets, since due to the design of SPIN, not all particles nucleate ice at the same time and not all the droplets necessarily evaporate in the evaporation section.

We investigated different SOA particle sizes from $120 \mathrm{~nm}$ to approximately $800 \mathrm{~nm}$ (see Table 1 for details). Figure 4 shows exemplary frozen fractions of 330,550 and $800 \mathrm{~nm}$ viscous SOA particles as a function of the ice saturation ratio.
The $330 \mathrm{~nm}$ particles were produced in the CLOUD chamber at $-38^{\circ} \mathrm{C}$, and at the time of ice formation the temperature inside SPIN was $-38.5 \pm 0.5^{\circ} \mathrm{C}$. The $550 \mathrm{~nm}$ particles were produced at $-20^{\circ} \mathrm{C}$, and nucleated ice at $-37.2 \pm 0.5^{\circ} \mathrm{C}$; the $800 \mathrm{~nm}$ particles produced at $-10^{\circ} \mathrm{C}$ nucleated ice at $-38.2 \pm 0.5^{\circ} \mathrm{C}$. The maximum frozen fractions observed were $\sim 6-20 \%$ but they did not show any clear dependency on the seed particle size; nor did the 1 or $10 \%$ ice activation onset values, although there is some variation among the different particle sizes. This can also be seen from Table S1 which details all the ice nucleation onset conditions from each experiment day.

SOA particle properties relevant for ice nucleation could depend on the chemical composition and morphology, which could depend on the chamber conditions. The mean atomic oxygen to carbon ratio $(\mathrm{O}: \mathrm{C})$ of the SOA particles inferred 


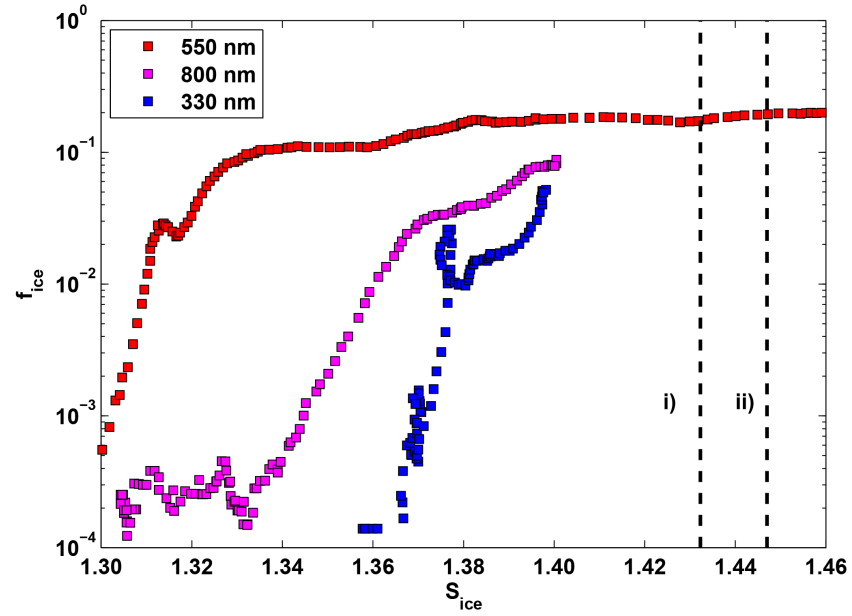

Figure 4. Examples of frozen fractions of viscous $\alpha$-pinene SOA obtained with SPIN as a function of the ice saturation ratio $S_{\text {ice }}$. The blue squares correspond to seed aerosol of $330 \mathrm{~nm}$, formed at $-38^{\circ} \mathrm{C}$, the red squares are the $550 \mathrm{~nm}$ particles, formed at $-20^{\circ} \mathrm{C}$, and the magenta squares are $800 \mathrm{~nm}$ particles, formed at $-10^{\circ} \mathrm{C}$. At the time of ice formation, the aerosol sample temperature inside SPIN was kept at approximately $-38.5^{\circ} \mathrm{C}$ for $330 \mathrm{~nm}$ particles; for $550 \mathrm{~nm}$ particles the temperature was at $-37.2^{\circ} \mathrm{C}$ and for $800 \mathrm{~nm}$ particles at $-38.2^{\circ} \mathrm{C}$. The black dashed vertical lines correspond to water saturation at (i) $-37^{\circ} \mathrm{C}$ and (ii) $-38^{\circ} \mathrm{C}$. Ice activation thresholds $(1,5,10 \%)$ were determined from similar ice activation graphs.

from AMS measurements was 0.25 throughout the different stages of the different experiments (Järvinen et al., 2016): this would suggest possibly similar chemical composition of the particles throughout the experiments. The apparent similarity in the chemical composition for different SOA particle sizes does not explain why there is no significant change in the frozen fraction or freezing onsets when the seed particles grow larger. Surface area dependency has previously been shown for deposition ice nucleation of different mineral dusts by Welti et al. (2009), but there is no indication of such a dependency for the viscous SOA particles studied here.

\subsection{Ice nucleation onset conditions for viscous SOA}

The ice nucleation onset conditions were systematically investigated for frozen fractions of 1,5 and $10 \%$. These data are listed in Table S1 in the Supplement. In general, the conditions for the observations of 1,5 and $10 \%$ frozen fractions were very similar. In Fig. 5 the conditions for $10 \%$ frozen fractions are depicted. In contrast to Fig. 2, the data in Fig. 5 were obtained from actual onset of ice formation as depicted in Fig. 3, not from ice offset measurements. The random instrumental error on the average aerosol sample temperature is expected to be similar to the variations observed above for homogeneous freezing with a standard deviation of $0.5^{\circ} \mathrm{C}$.

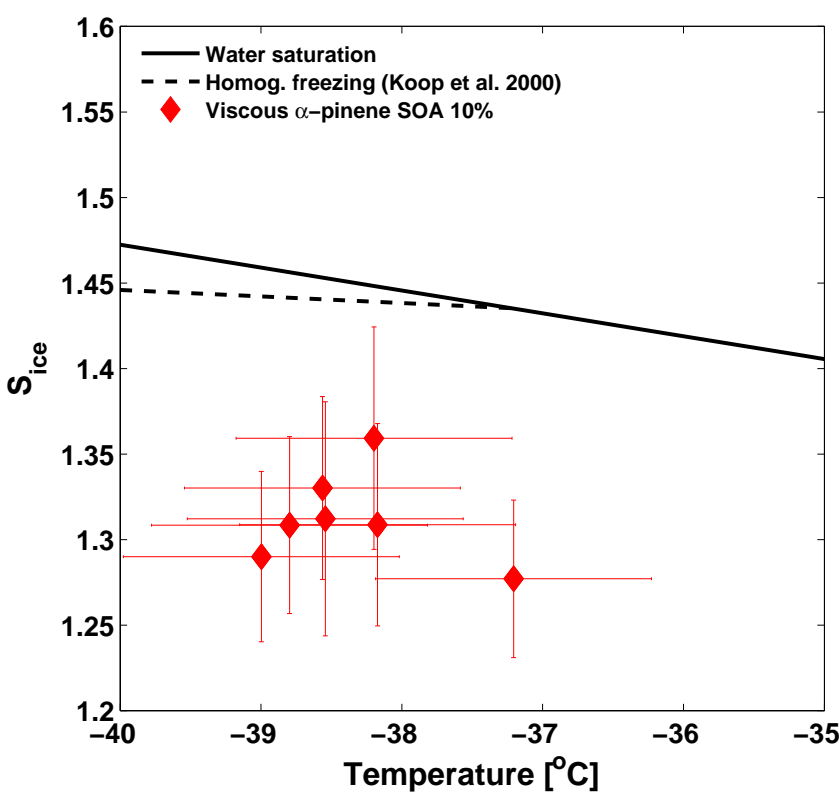

Figure 5. Ice nucleation onsets (10\% activation) for $\alpha$-pinene SOA The horizontal error bars of the ice nucleation data represent statistical $95 \%$ confidence interval in temperature and are calculated from the instrumentally determined standard deviation of $0.5^{\circ} \mathrm{C}$ in the homogeneous freezing experiments. The error bars in ice saturation ratio illustrate the modelled maximum equilibrium range the aerosol sample can be exposed to.

The depicted range of the saturation ratio with respect to ice $\left(S_{\text {ice }}\right)$ is the modelled equilibrium maximum range the aerosol sample possibly is exposed to - in the vertical and horizontal dimensions - based on the pairwise temperature readings of the chamber walls at four locations. This is illustrated in Fig. S1 in the Supplement. The modelling is done by taking the warm and cold wall temperature pairs at the four thermocouple locations where they are monitored and then calculating the aerosol lamina temperatures and saturation ratios with respect water and ice at those locations according to Rogers (1988). The reported ice nucleation onset temperatures in Fig. 5 are the mean values of the four aerosol lamina temperatures, and the reported $S_{\text {ice }}$ values are the mean values of the four calculated lamina $S_{\text {ice }}$ values. All the maximum saturation ratios for the observed $10 \%$ frozen fractions are below the depicted lines in Fig. 5 indicating where homogeneous freezing occurs. In terms of the saturation ratio with respect to water, the maximum modelled values are found in the range $0.90-0.98$ and in the range $0.92-0.98$ for frozen fractions of 1 and $10 \%$, respectively. For the water saturation to reach 1 for all of these freezing conditions, a systematic wall temperature deviation in between thermocouples of $>2{ }^{\circ} \mathrm{C}$ would be required. Such a systematic wall temperature deviation is highly unlikely considering the reasonable and reproducible homogeneous freezing results presented above. Hence, it is highly unlikely that the observed 
freezing occurring at subsaturated conditions with respect to water is homogeneous freezing.

From our measurements, we have a strong indication that the studied $\alpha$-pinene SOA induced ice nucleation heterogeneously. Despite instrumental limitations, the results were reproducible and the uncertainty for the ice nucleation onset temperatures and supersaturations could be inferred.

\subsection{Freezing mechanisms}

The results presented in the section above clearly indicate heterogeneous freezing of SOA particles below saturation with respect to water vapour. Various freezing mechanisms could potentially be in play. It can be speculated that we observe (i) deposition nucleation occurring directly onto highly viscous SOA particles; (ii) immersion freezing of partly deliquesced SOA particles, where the core of the particle is still (highly) viscous; (iii) hygroscopic growth of the particles leading to freezing of droplets due to suspensions of large organic molecules. The relevance of the first two potential freezing processes are related to the relative timescales of the viscosity transition vs the freezing of the SOA particles for increasing humidities as discussed e.g. by Berkemeier et al. (2014), Lienhard et al. (2015) and Price et al. (2015). Lienhard et al. (2015) conclude that heterogeneous freezing of biogenic SOA particles would be highly unlikely at temperatures higher than $220 \mathrm{~K}$ in the atmosphere since according to their modelling, the timescales of equilibration would be very short. On the other hand, the modelling results presented by Price et al. (2015) indicate that $\alpha$-pinene SOA particles are likely to exhibit viscous core-liquified shell morphologies on timescales long enough to facilitate ice nucleation via the suggested mechanism (ii) in our study.

In this context, it is worth mentioning that the maximum ice nucleation time in SPIN is of the order of $10 \mathrm{~s}$. However, nucleation taking place on much shorter timescales can be observed if the nucleation rates are high enough to yield detectable numbers of ice crystals. In other words, the observed number of ice crystals corresponds to the time integral over the nucleation rate distribution. This implies that from our measurements, no further conclusions concerning nucleation times and rates can be drawn.

The (iii) potential freezing mechanism has been reported for ice nucleating macromolecules (INM) originating from pollen (Pummer et al., 2012). It is not likely that the molecules formed in the current study grow to masses comparable to the several $\mathrm{kDa}$ reported for the pollen macromolecules (Pummer et al., 2012), but it does not necessarily rule out that large enough molecules or agglomerates to facilitate freezing may have been produced during the conducted experiments, even though it did not seem to be the case in previous comparable studies (Möhler et al., 2008; Ladino et al., 2014). Based on the current study, it is not possible to conclude which heterogeneous freezing mechanism(s) may be dominating.

\subsection{Comparison to literature data}

Figure 6 shows our results together with selected literature data. The ice saturation ratios we have observed for the ice nucleation onset temperatures for viscous $\alpha$-pinene SOA are qualitatively comparable with ice nucleation data from other SOA or SOA proxies, but the lack of data points at lower temperatures makes quantitative comparison challenging. There is a notable difference between our results and those reported by Ladino et al. (2014) and Möhler et al. (2008), who found $\alpha$-pinene SOA to be a poor INP, nucleating ice homogeneously. However, Ladino et al. (2014) also found that precooling of the particles made them slightly better INPs, and interpret it as a result of a transition to a more viscous state, although the phase state of the particles was not studied experimentally.

When comparing the frozen fractions of this study to earlier studies with SOA proxies, such as the substances studied by Wilson et al. (2012) and Murray et al. (2010), it is worth noting that much higher frozen fractions are achieved in this study. Most likely the difference lies in the experimental methods used: in Wilson et al. (2012) and Murray et al. (2010), the freezing was studied in an expansion chamber, not a continuous flow diffusion chamber such as SPIN. Thus, we would also not necessarily expect similar frozen fractions

When compared to other INPs, such as different mineral dusts, viscous $\alpha$-pinene SOA requires higher ice saturation ratios for $10 \%$ activated fraction than e.g. kaolinite and illite at -35 and $-40^{\circ} \mathrm{C}$ (Welti et al., 2009). The maximum ice fractions, on the other hand, are of the same order of magnitude. The viscous SOA particles seem to be more efficient INPs than volcanic ash at -35 and $-40{ }^{\circ} \mathrm{C}$ measured by Hoyle et al. (2011), with similar or lower ice saturation ratios needed for $10 \%$ activation and higher maximum ice fractions.

\subsection{Atmospheric implications}

Viscous pinene SOA particles have already been observed in the lower troposphere in field measurements in the boreal forest (Virtanen et al., 2010). The global aerosol model GLOMAP-mode (GLObal Model of Aerosol Processes) (Mann et al., 2010) was used to investigate to what extent viscous biogenic monoterpene SOA is likely to be present in the atmosphere. The model version used is identical to that in Riccobono et al. (2014). GLOMAP is an extension to the TOMCAT chemical transport model (Chipperfield, 2006). It includes representations of particle formation, growth via coagulation, condensation and cloud processing, wet and dry deposition and in/below cloud scavenging. The horizontal resolution is $2.8^{\circ} \times 2.8^{\circ}$ and there are 31 vertical sigma-pressure levels extending from ground level to $10 \mathrm{hPa}$. Formation of secondary particles in the model is based on CLOUD measurements of ternary $\mathrm{H}_{2} \mathrm{SO}_{4}$-organic$\mathrm{H}_{2} \mathrm{O}$ nucleation detailed in Riccobono et al. (2014) and on 

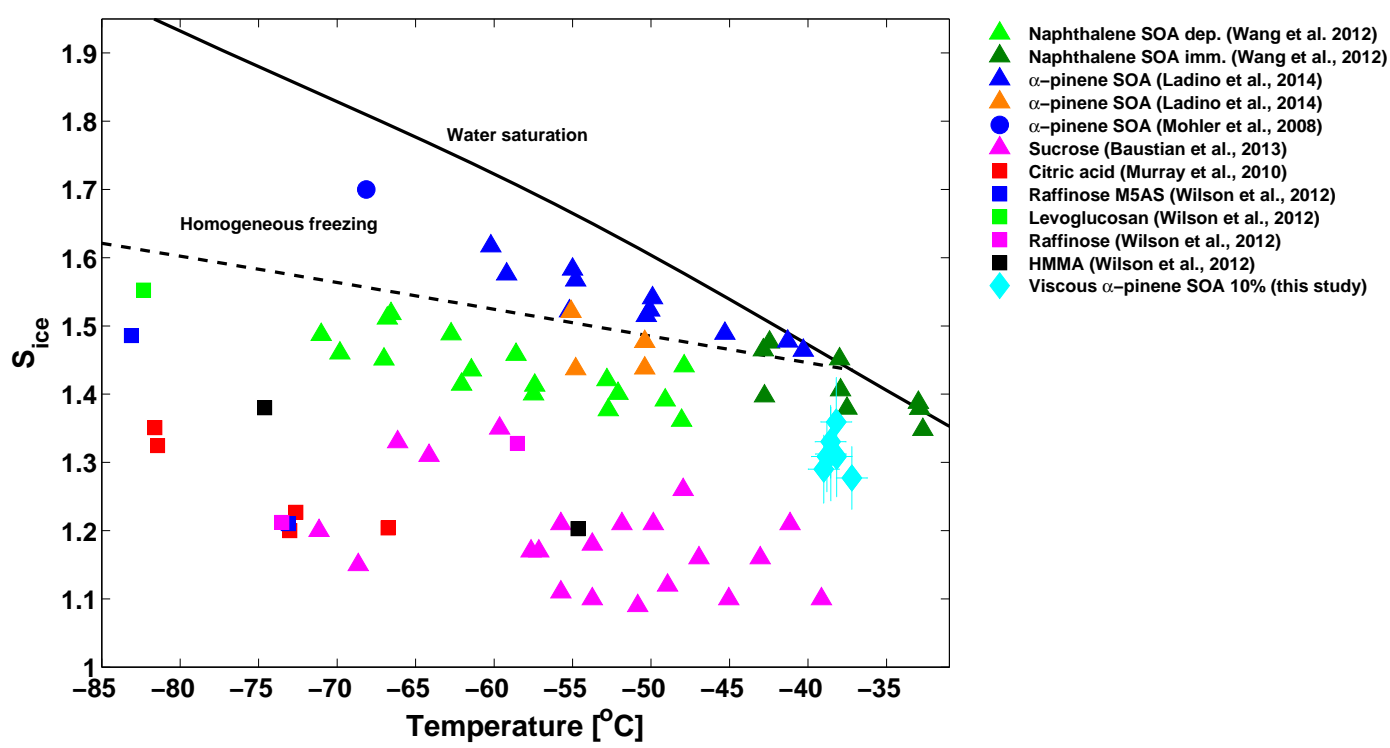

Figure 6. Comparison of ice nucleation onsets of different SOA species and proxies. The black solid line is the water saturation line and the black dashed line the Koop et al. (2000) homogeneous freezing line for $500 \mathrm{~nm}$ particles. The cyan diamonds represent the results of this study; the light and dark green triangles deposition nucleation and immersion freezing of naphthalene SOA from Wang et al. (2012); the magenta triangles deposition ice nucleation of sucrose from Baustian et al. (2013); the blue triangles ice nucleation of $\alpha$-pinene SOA studied by Ladino et al. (2014) and the orange triangles pre-cooled $\alpha$-pinene SOA from the same study; and the blue circle depicts the homogeneous freezing of pure $\alpha$-pinene SOA reported by Möhler et al. (2008). The red squares show the deposition ice nucleation onsets for glassy citric acid (Murray et al., 2010), and the freezing results of four glassy SOA proxies from Wilson et al. (2012) are shown by blue squares (raffinose M5AS), green squares (levoglucosan), magenta squares (raffinose), and black squares (HMMA).

a parameterization of binary $\mathrm{H}_{2} \mathrm{SO}_{4}-\mathrm{H}_{2} \mathrm{O}$ nucleation (Kulmala et al., 1998). Particles grow by irreversible condensation of monoterpene oxidation products and sulphuric acid. Monoterpene emissions in the model are taken from the Guenther et al. (1995) database. The monoterpenes are oxidized with $\mathrm{OH}, \mathrm{O}_{3}$ and $\mathrm{NO}_{3}$ assuming the reaction rates of $\alpha$-pinene. A fixed $13 \%$ of the oxidation products, referred to as SORG, condenses irreversibly onto aerosol particles at the kinetic limit.

Figure 7 shows the mean annual average concentrations of SORG in parts per trillion with respect to mass (pptm). SORG represents oxidized monoterpenes and can in this respect be considered a proxy of monoterpene SOA particles. The hatched areas mark the zones in the atmosphere where the SOA particles are likely to exist in a highly viscous or even glassy phase state according to the generic estimate of SOA glass transition temperature as a function of relative humidity given by Koop et al. (2011). This parameterization agrees with the viscosity transitions of the investigated $\alpha$-pinene SOA particles that were measured in the CLOUD chamber simultaneously with the ice nucleation experiments (Järvinen et al., 2016; Nichman et al., 2016).

The modelled monoterpene SOA proxy concentrations are highest over land and especially in the tropics, but near the equator the conditions for particles containing monoterpene SOA to be highly viscous require higher altitudes $(\sim 7 \mathrm{~km})$ and colder temperatures (see Fig. 7 right panel). On the other hand, strong convective updrafts may play a role carrying the SOA particles even into the tropical tropopause layer (TTL) in short enough timescales for the particles to remain highly viscous (Berkemeier et al., 2014; Price et al., 2015), or SOA may form in convective outflow regions, after the transport of precursor gases from lower altitudes in the troposphere. Boreal forests are a significant source of monoterpenes in spring and summertime of the Northern Hemisphere, and model calculations displayed in Fig. 7 indicate that sufficient concentrations of viscous monoterpene SOA could exist in the upper troposphere in this region, thus being a potential source of INPs for cirrus cloud formation. This is relevant assuming that the freezing mechanism is deposition nucleation of highly viscous SOA or immersion freezing of partly deliquesced SOA with a highly viscous core. It should be noted that also particles with other types of SOA than $\alpha$ pinene SOA may facilitate ice nucleation in cirrus clouds, or persist in a viscous state at higher temperatures or humidities (Berkemeier et al., 2014). The model results presented here nevertheless indicate qualitatively that significant concentrations of SOA-forming vapours are likely to exist in parts of the troposphere where the particles they form would be in a sufficiently viscous state to act as INPs depositionally or via immersion freezing. On the other hand, if the freezing is initiated by organic INM suspended in droplets, high viscosity might not be a prerequisite for biogenic SOA to act as an INP. 

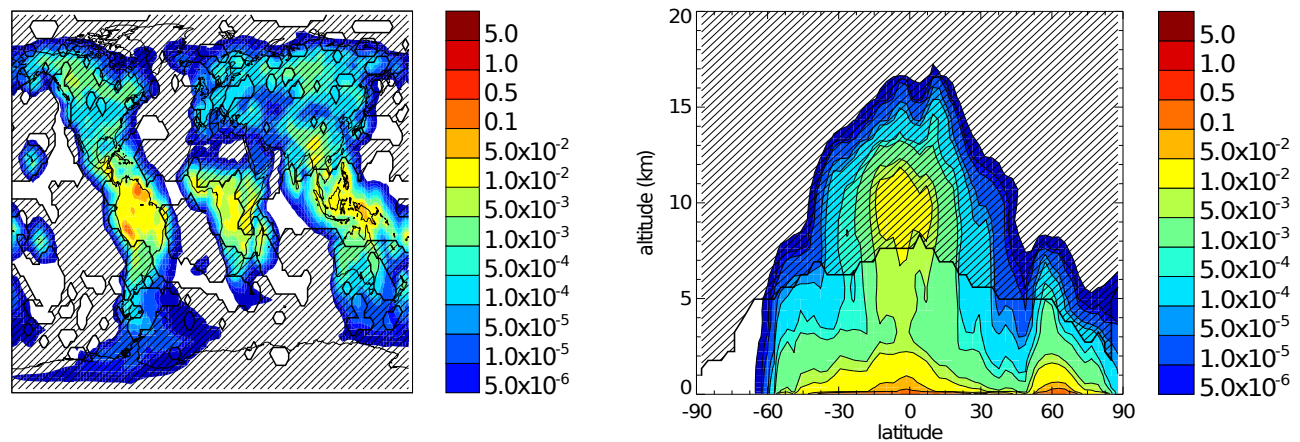

Figure 7. GLOMAP model predictions of mean annual concentrations of condensible oxidation products of monoterpenes, SORG. The concentrations shown by the colour scale are in parts per trillion with respect to mass (pptm). The hatched areas represent the zones where the SOA particles could exist in a highly viscous or amorphous phase state in the upper troposphere and potentially affect cirrus cloud formation through deposition ice nucleation or immersion freezing. The calculations for these zones are based on the theoretical estimate of generic SOA glass transition temperature as a function of relative humidity presented by Koop et al. (2011). The left panel shows a global map of the mean annual concentrations of SORG at a sigma-pressure level corresponding to approximately $6900 \mathrm{~m}$ altitude from a simulation of the year 2000. In the right panel, annual zonal mean of global concentrations of SORG are plotted as a function of latitude and altitude.

So far, SOA has not been considered in climate models involving ice nucleation, and it is still very challenging to quantify the actual effect, but given the potentially high ice nucleation efficiency (up to $20 \%$ frozen fractions), $\alpha$-pinene and other monoterpene SOA could contribute significantly to the global INP budget. It is likely that a significant portion of biogenic SOA in the atmosphere forms mixtures with sulphates or primary particles such as mineral dusts, which will most likely also affect the ice nucleation efficiency considerably. It has already been shown that glassy aerosol containing a mixture of carboxylic acids and ammonium sulphate nucleates ice (Wilson et al., 2012).

\section{Conclusions}

In this study, we produced viscous $\alpha$-pinene SOA particles at $10 \% \mathrm{RH}$ at four different atmospherically relevant subzero temperatures, $-10,-20,-30$ and $-38^{\circ} \mathrm{C}$, and measured their ice nucleation capability with a new portable INP counter. We have, for the first time, found a strong indication that SOA produced from ozonolysis of $\alpha$-pinene efficiently nucleates ice. We conducted reproducible measurements and performed uncertainty estimation and modelling of the temperatures and ice saturation ratios inside the INP counter to determine that the ice nucleation was heterogeneous. We investigated SOA particles with mean diameters from 120 to $800 \mathrm{~nm}$, and no dependency was observed between the particle size and the frozen fraction/freezing onset. The frozen fractions reached a maximum of $\sim 6-20 \%$. Ice saturation ratios for the observed ice nucleation onset temperatures are in line with previous literature data, but the range of observed ice nucleation onset temperatures was narrow due to instrumental limitations. We were not able to distinguish between three possible freezing mechanisms: (i) deposition nu- cleation onto highly viscous SOA particles; (ii) immersion freezing of partly deliquesced SOA particles; or (iii) hygroscopic growth and subsequent freezing of the SOA particles due to presence of organic ice nucleating macromolecules. Therefore, further experimental studies are recommended.

To date, biogenic SOA has not been considered as an INP in any climate models. Here, results from a global aerosol model suggest that $\alpha$-pinene SOA may exist at least regionally in considerable numbers in the upper troposphere in the cirrus regime where they would be highly viscous or glassy, which is relevant for the freezing mechanisms (i) and (ii) above. Thus boreal forests and other regions emitting monoterpenes could potentially be a significant source of INPs contributing to the global INP budget. In order to better quantify the impact of biogenic SOA as an INP to the climate, extensive future experimental and modelling studies will be needed.

\section{The Supplement related to this article is available online at doi:10.5194/acp-16-6495-2016-supplement.}

Acknowledgements. We would like to thank Luis Ladino, Kelly Baustian, Daniel Knopf, Bingbing Wang and Theo Wilson for providing the data for comparison and useful discussions. We also thank CERN CLOUD technical staff and all the ITN students for their help and support, and Dan Cziczo and Thomas Conrath for assistance in SPIN development. This research has received funding from the EC seventh Framework Programme (Marie Curie Initial Training Networks MC-ITN CLOUD-TRAIN grant no. 316662), the German Federal Ministry of Education and Research (BMBF) through the CLOUD-12 project (no. 01LK1222B), the Swiss National Science Foundation SNSF (grant no. 200021 140663), from NordForsk through the Nordic Centre of Excellence 
CRAICC (Cryosphere-Atmosphere Interactions in a Changing Arctic Climate), the US National Science Foundation (grants AGS1439551, AGS1447056), the Academy of Finland (decision no. 259005) and the European Research Council (ERC Starting Grant 335478).

Edited by: H. Grothe

\section{References}

Adler, G., Koop, T., Haspel, C., Taraniuk, I., Moise, T., Koren, I., Heiblum, R. H., and Rudich, Y.: Formation of highly porous aerosol particles by atmospheric freeze-drying in ice clouds, $\mathrm{P}$. Natl. Acad. Sci. USA, 110, 20414-20419, 2013.

Baustian, K. J., Wise, M. E., Jensen, E. J., Schill, G. P., Freedman, M. A., and Tolbert, M. A.: State transformations and ice nucleation in amorphous (semi-)solid organic aerosol, Atmos. Chem. Phys., 13, 5615-5628, doi:10.5194/acp-13-5615-2013, 2013.

Berkemeier, T., Shiraiwa, M., Pöschl, U., and Koop, T.: Competition between water uptake and ice nucleation by glassy organic aerosol particles, Atmos. Chem. Phys., 14, 12513-12531, doi:10.5194/acp-14-12513-2014, 2014.

Chipperfield, M. P.: New version of the TOMCAT/SLIMCAT offline chemical transport model: intercomparison of stratospheric tracer experiments, Q. J. Roy. Meteor. Soc., 132, 1179-1203, 2006.

Chou, C., Stetzer, O., Weingartner, E., Jurányi, Z., Kanji, Z. A., and Lohmann, U.: Ice nuclei properties within a Saharan dust event at the Jungfraujoch in the Swiss Alps, Atmos. Chem. Phys., 11, 4725-4738, doi:10.5194/acp-11-4725-2011, 2011.

Connolly, P. J., Möhler, O., Field, P. R., Saathoff, H., Burgess, R., Choularton, T., and Gallagher, M.: Studies of heterogeneous freezing by three different desert dust samples, Atmos. Chem. Phys., 9, 2805-2824, doi:10.5194/acp-9-2805-2009, 2009.

Cziczo, D. J., Froyd, K. D., Hoose, C., Jensen, E. J., Diao, M. H., Zondlo, M. A., Smith, J. B., Twohy, C. H., and Murphy, D. M.: Clarifying the dominant sources and mechanisms of cirrus cloud formation, Science, 340, 1320-1324, 2013.

DeMott, P. J., Sassen, K., Poellot, M. R., Baumgardner, D., Rogers, D. C., Brooks, S. D., Prenni, A. J., and Kreidenweis, S. M.: African dust aerosols as atmospheric ice nuclei, Geophys. Res. Lett., 30, 1732, doi:10.1029/2003GL017410, 2003.

DeMott, P. J., Prenni, A. J., Liu, X., Kreidenweis, S. M., Petters, M. D., Twohy, C. H., Richardson, M. S., Eidhammer, T., and Rogers, D. C.: Predicting global atmospheric ice nuclei distributions and their impacts on climate, P. Natl. Acad. Sci. USA, 107, 11217-11222, 2010.

Duplissy, J., Enghoff, M. B., Aplin, K. L., Arnold, F., Aufmhoff, H., Avngaard, M., Baltensperger, U., Bondo, T., Bingham, R., Carslaw, K., Curtius, J., David, A., Fastrup, B., Gagné, S., Hahn, F., Harrison, R. G., Kellett, B., Kirkby, J., Kulmala, M., Laakso, L., Laaksonen, A., Lillestol, E., Lockwood, M., Mäkelä, J., Makhmutov, V., Marsh, N. D., Nieminen, T., Onnela, A., Pedersen, E., Pedersen, J. O. P., Polny, J., Reichl, U., Seinfeld, J. H., Sipilä, M., Stozhkov, Y., Stratmann, F., Svensmark, H., Svensmark, J., Veenhof, R., Verheggen, B., Viisa- nen, Y., Wagner, P. E., Wehrle, G., Weingartner, E., Wex, H., Wilhelmsson, M., and Winkler, P. M.: Results from the CERN pilot CLOUD experiment, Atmos. Chem. Phys., 10, 1635-1647, doi:10.5194/acp-10-1635-2010, 2010.

Duplissy, J., Merikanto, J., Franchin, A., Tsagkogeorgas, G., Kangasluoma, J., Wimmer, D., Vuollekoski, H., Schobesberger, S., Lehtipalo, K., Flagan, R. C., Brus, D., Donahue, N. M., Vehkamäki, H., Almeida, J., Amorim, A., Barmet, P., Bianchi, F., Breitenlechner, M., Dunne, E. M., Guida, R., Henschel, H., Junninen, H., Kirkby, J., Kürten, A., A., K., Määttänen, A., Makhmutov, V., Mathot, S., Nieminen, T., Onnela, A., Praplan, A. P., Riccobono, F., Rondo, L., Steiner, G., Tomé, A., Walther, H., Baltensperger, U., Carslaw, K. S., Dommen, J., Hansel, A., Petäjä, T., Sipilä, M., Stratmann, F., Virtanen, A., Wagner, P. E., Worsnop, D. R., Curtius, J., and Kulmala, M.: Effect of ions on sulfuric acid-water binary particle formation II: Experimental data and comparison with QC-normalized classical nucleation theory, J. Geophys. Res., 121, 1752-1775, doi:10.1002/2015JD023539, 2016.

Froyd, K. D., Murphy, D. M., Sanford, T. J., Thomson, D. S., Wilson, J. C., Pfister, L., and Lait, L.: Aerosol composition of the tropical upper troposphere, Atmos. Chem. Phys., 9, 4363-4385, doi:10.5194/acp-9-4363-2009, 2009.

Froyd, K. D., Murphy, D. M., Lawson, P., Baumgardner, D., and Herman, R. L.: Aerosols that form subvisible cirrus at the tropical tropopause, Atmos. Chem. Phys., 10, 209-218, doi:10.5194/acp10-209-2010, 2010.

Garimella, S., Kristensen, T. B., Ignatius, K., Welti, A., Voigtländer, J., Kulkarni, G. R., Sagan, F., Kok, G. L., Dorsey, J., Nichman, L., Rothenberg, D., Rösch, M., Kirchgäßner, A., Ladkin, R., Wex, H., Wilson, T. W., Ladino, L. A., Abbatt, J. P. D., Stetzer, O., Lohmann, U., Stratmann, F., and Cziczo, D. J.: The SPectrometer for Ice Nuclei (SPIN): An instrument to investigate ice nucleation, Atmos. Meas. Tech. Discuss., doi:10.5194/amt-2015-400, in review, 2016.

Guenther, A., Hewitt, C. N., Erickson, D., Fall, R., Geron, C., Graedel, T., Harley, P., Klinger, L., Lerdau, M., Mckay, W. A., Pierce, T., Scholes, B., Steinbrecher, R., Tallamraju, R., Taylor, J., and Zimmerman, P.: A global model of natural volatile organic compound emissions, J. Geophys. Res.-Atmos., 100, 8873-8892, 1995.

Guenther, A., Karl, T., Harley, P., Wiedinmyer, C., Palmer, P. I., and Geron, C.: Estimates of global terrestrial isoprene emissions using MEGAN (Model of Emissions of Gases and Aerosols from Nature), Atmos. Chem. Phys., 6, 3181-3210, doi:10.5194/acp-63181-2006, 2006.

Hallquist, M., Wenger, J. C., Baltensperger, U., Rudich, Y., Simpson, D., Claeys, M., Dommen, J., Donahue, N. M., George, C., Goldstein, A. H., Hamilton, J. F., Herrmann, H., Hoffmann, T., Iinuma, Y., Jang, M., Jenkin, M. E., Jimenez, J. L., KiendlerScharr, A., Maenhaut, W., McFiggans, G., Mentel, Th. F., Monod, A., Prévôt, A. S. H., Seinfeld, J. H., Surratt, J. D., Szmigielski, R., and Wildt, J.: The formation, properties and impact of secondary organic aerosol: current and emerging issues, Atmos. Chem. Phys., 9, 5155-5236, doi:10.5194/acp-9-51552009, 2009. 
Hoose, C. and Möhler, O.: Heterogeneous ice nucleation on atmospheric aerosols: a review of results from laboratory experiments, Atmos. Chem. Phys., 12, 9817-9854, doi:10.5194/acp-12-98172012, 2012.

Hoyle, C. R., Pinti, V., Welti, A., Zobrist, B., Marcolli, C., Luo, B., Höskuldsson, Á., Mattsson, H. B., Stetzer, O., Thorsteinsson, T., Larsen, G., and Peter, T.: Ice nucleation properties of volcanic ash from Eyjafjallajökull, Atmos. Chem. Phys., 11, 9911-9926, doi:10.5194/acp-11-9911-2011, 2011.

Hoyle, C. R., Fuchs, C., Järvinen, E., Saathoff, H., Dias, A., El Haddad, I., Gysel, M., Coburn, S. C., Tröstl, J., Bernhammer, A.-K., Bianchi, F., Breitenlechner, M., Corbin, J. C., Craven, J., Donahue, N. M., Duplissy, J., Ehrhart, S., Frege, C., Gordon, H., Höppel, N., Heinritzi, M., Kristensen, T. B., Molteni, U., Nichman, L., Pinterich, T., Prévôt, A. S. H., Simon, M., Slowik, J. G., Steiner, G., Tomé, A., Vogel, A. L., Volkamer, R., Wagner, A. C., Wagner, R., Wexler, A. S., Williamson, C., Winkler, P. M., Yan, C., Amorim, A., Dommen, J., Curtius, J., Gallagher, M. W., Flagan, R. C., Hansel, A., Kirkby, J., Kulmala, M., Möhler, O., Stratmann, F., Worsnop, D. R., Baltensperger, U.: Aqueous phase oxidation of sulphur dioxide by ozone in cloud droplets, Atmos. Chem. Phys., 16, 1693-1712, doi:10.5194/acp-16-16932016, 2016.

Ickes, L., Welti, A., Hoose, C., and Lohmann, U.: Classical nucleation theory of homogeneous freezing of water: thermodynamic and kinetic parameters, Phys. Chem. Chem. Phys., 17, 55145537, 2015.

Järvinen, E., Ignatius, K., Nichman, L., Kristensen, T. B., Fuchs, C., Hoyle, C. R., Höppel, N., Corbin, J. C., Craven, J., Duplissy, J., Ehrhart, S., El Haddad, I., Frege, C., Gordon, H., Jokinen, T., Kallinger, P., Kirkby, J., Kiselev, A., Naumann, K.-H., Petäjä, T., Pinterich, T., Prevot, A. S. H., Saathoff, H., Schiebel, T., Sengupta, K., Simon, M., Slowik, J. G., Tröstl, J., Virtanen, A., Vochezer, P., Vogt, S., Wagner, A. C., Wagner, R., Williamson, C., Winkler, P. M., Yan, C., Baltensperger, U., Donahue, N. M., Flagan, R. C., Gallagher, M., Hansel, A., Kulmala, M., Stratmann, F., Worsnop, D. R., Möhler, O., Leisner, T., and Schnaiter, M.: Observation of viscosity transition in $\alpha$-pinene secondary organic aerosol, Atmos. Chem. Phys., 16, 4423-4438, doi:10.5194/acp-16-4423-2016, 2016.

Jimenez, J. L., Canagaratna, M. R., Donahue, N. M., Prevot, A. S. H., Zhang, Q., Kroll, J. H., DeCarlo, P. F., Allan, J. D., Coe, H., Ng, N. L., Aiken, A. C., Docherty, K. S., Ulbrich, I. M., Grieshop, A. P., Robinson, A. L., Duplissy, J., Smith, J. D., Wilson, K. R., Lanz, V. A., Hueglin, C., Sun, Y. L., Tian, J., Laaksonen, A., Raatikainen, T., Rautiainen, J., Vaattovaara, P., Ehn, M., Kulmala, M., Tomlinson, J. M., Collins, D. R., Cubison, M. J. E., Dunlea, J., Huffman, J. A., Onasch, T. B., Alfarra, M. R., Williams, P. I., Bower, K., Kondo, Y., Schneider, J., Drewnick, F., Borrmann, S., Weimer, S., Demerjian, K., Salcedo, D., Cottrell, L., Griffin, R., Takami, A., Miyoshi, T., Hatakeyama, S., Shimono, A., Sun, J. Y., Zhang, Y. M., Dzepina, K., Kimmel, J. R., Sueper, D., Jayne, J. T., Herndon, S. C., Trimborn, A. M., Williams, L. R., Wood, E. C., Middlebrook, A. M., Kolb, C. E., Baltensperger, U., and Worsnop, D. R.: Evolution of organic aerosols in the atmosphere, Science, 365, 1525-1529, 2009

Kanakidou, M., Seinfeld, J. H., Pandis, S. N., Barnes, I., Dentener, F. J., Facchini, M. C., Van Dingenen, R., Ervens, B.,
Nenes, A., Nielsen, C. J., Swietlicki, E., Putaud, J. P., Balkanski, Y., Fuzzi, S., Horth, J., Moortgat, G. K., Winterhalter, R., Myhre, C. E. L., Tsigaridis, K., Vignati, E., Stephanou, E. G., and Wilson, J.: Organic aerosol and global climate modelling: a review, Atmos. Chem. Phys., 5, 1053-1123, doi:10.5194/acp-51053-2005, 2005.

Kirkby, J., Curtius, J., Almeida, J., Dunne, E., Duplissy, J., Ehrhart, S., Franchin, A., Gagne, S., Ickes, L., Kürten, A., Kupc, A., Metzger, A., Riccobono, F., Rondo, L., Schobesberger, S., Tsagkogeorgas, G., Wimmer, D., Amorim, A., Bianchi, F., Breitenlechner, M., David, A., Dommen, J., Downard, A., Ehn, M., Flagan, R. C., Haider, S., Hansel, A., Hauser, D., Jud, W., Junninen, H., Kreissl, F., Kvashin, A., Laaksonen, A., Lehtipalo, K., Lima, J., Lovejoy, E. R., Makhmutov, V., Mathot, S., Mikkilä, J., Minginette, P., Mogo, S., Nieminen, T., Onnela, A., Pereira, P., Petäjä, T., Schnitzhofer, R., Seinfeld, J. H., Sipilä, M., Stozhkov, Y., Stratmann, F., Tomé, A., Vanhanen, J., Viisanen, Y., Vrtala, A., Wagner, P. E., Walther, H., Weingartner, E., Wex, H., Winkler, P. M., Carslaw, K. E., Worsnop, D. R., Baltensperger, U., and Kulmala, M.: Role of sulphuric acid, ammonia and galactic cosmic rays in atmospheric aerosol nucleation, Nature, 476, 429-433, 2011.

Koop, T., Luo, B., Tsias, A., and Peter, T.: Water activity as the determinant for homogeneous ice nucleation in aqueous solutions, Nature, 406, 611-614, 2000.

Koop, T., Bookhold, J., Shiraiwa, M., and Pöschl, U.: Glass transition and phase state of organic compounds: dependency on molecular properties and implications for secondary organic aerosols in the atmosphere, Phys. Chem. Chem. Phys., 13, 19238-19255, 2011.

Krämer, M., Schiller, C., Afchine, A., Bauer, R., Gensch, I., Mangold, A., Schlicht, S., Spelten, N., Sitnikov, N., Borrmann, S., de Reus, M., and Spichtinger, P.: Ice supersaturations and cirrus cloud crystal numbers, Atmos. Chem. Phys., 9, 3505-3522, doi:10.5194/acp-9-3505-2009, 2009.

Kulmala, M., Laaksonen, A., and Pirjola, L.: Parameterizations for sulfuric acid/water nucleation rates, J. Geophys. Res., 103, 83018307, 1998.

Laaksonen, A., Kulmala, M., O’Dowd, C. D., Joutsensaari, J., Vaattovaara, P., Mikkonen, S., Lehtinen, K. E. J., Sogacheva, L., Dal Maso, M., Aalto, P., Petäjä, T., Sogachev, A., Yoon, Y. J., Lihavainen, H., Nilsson, D., Facchini, M. C., Cavalli, F., Fuzzi, S., Hoffmann, T., Arnold, F., Hanke, M., Sellegri, K., Umann, B., Junkermann, W., Coe, H., Allan, J. D., Alfarra, M. R., Worsnop, D. R., Riekkola, M.-L., Hyötyläinen, T., and Viisanen, Y.: The role of VOC oxidation products in continental new particle formation, Atmos. Chem. Phys., 8, 2657-2665, doi:10.5194/acp-8-2657-2008, 2008.

Ladino, L. A., Zhou, S., Yakobi-Hancock, J. D., Aljawhary, D., and Abbatt, J. P. D.: Factors controlling the ice nucleating abilities of $\alpha$-pinene SOA particles, J. Geophys. Res.-Atmos., 119, 90419051, 2014.

Lienhard, D. M., Huisman, A. J., Krieger, U. K., Rudich, Y., Marcolli, C., Luo, B. P., Bones, D. L., Reid, J. P., Lambe, A. T., Canagaratna, M. R., Davidovits, P., Onasch, T. B., Worsnop, D. R., Steimer, S. S., Koop, T. and Peter, T.: Viscous organic aerosol particles in the upper troposphere: diffusivity-controlled water uptake and ice nucleation?, Atmos. Chem. Phys., 15, 1359913613, 2015. 
Mann, G. W., Carslaw, K. S., Spracklen, D. V., Ridley, D. A., Manktelow, P. T., Chipperfield, M. P., Pickering, S. J., and Johnson, C. E.: Description and evaluation of GLOMAP-mode: a modal global aerosol microphysics model for the UKCA composition-climate model, Geosci. Model Dev., 3, 519-551, doi:10.5194/gmd-3-519-2010, 2010.

Möhler, O., Field, P. R., Connolly, P., Benz, S., Saathoff, H., Schnaiter, M., Wagner, R., Cotton, R., Krämer, M., Mangold, A., and Heymsfield, A. J.: Efficiency of the deposition mode ice nucleation on mineral dust particles, Atmos. Chem. Phys., 6, 30073021, doi:10.5194/acp-6-3007-2006, 2006.

Möhler, O., Benz, S., Saathoff, H., Schnaiter, M., Wagner, R., Schneider, J., Walter, S., Ebert, V., and Wagner, S.: The effect of organic coating on the heterogeneous ice nucleation efficiency of mineral dust aerosols, Environ. Res. Lett., 3, 025007, doi:10.1088/1748-9326/3/2/025007, 2008.

Murray, B. J., Wilson, T. W., Dobbie, S., Cui, Z., Al-Jumur, S. M., Möhler, O., Schnaiter, M., Wagner, R., Benz, S., Niemand, M., Saathoff, H., Ebert, V., Wagner, S., and Kärcher, B.: Heterogeneous nucleation of ice particles on glassy aerosols under cirrus conditions, Nat. Geosci., 3, 233-237, 2010.

Murray, B. J., O'Sullivan, D., Atkinson, J. D., and Webb, M. E. : Ice nucleation by particles immersed in supercooled cloud droplets, Chem. Soc. Rev., 41, 6519-6554, 2012.

Nichman, L., Fuchs, C., Järvinen, E., Ignatius, K., Höppel, N. F., Dias, A., Heinritzi, M., Simon, M., Tröstl, J., Wagner, A. C., Wagner, R., Williamson, C., Yan, C., Connolly, P. J., Dorsey, J. R., Duplissy, J., Ehrhart, S., Frege, C., Gordon, H., Hoyle, C. R., Kristensen, T. B., Steiner, G., McPherson Donahue, N., Flagan, R., Gallagher, M. W., Kirkby, J., Möhler, O., Saathoff, H., Schnaiter, M., Stratmann, F., and Tomé, A.: Phase transition observations and discrimination of small cloud particles by light polarization in expansion chamber experiments, Atmos. Chem. Phys., 16, 3651-3664, doi:10.5194/acp-16-3651-2016, 2016.

Pajunoja, A., Lambe, A. T., Hakala, J., Rastak, N., Cummings, M. J., Brogan, J. F., Hao, L., Paramonov, M., Hong, J., Prisle, N. L., Malila, J., Romakkaniemi, S., Lehtinen, K. E. J., Laaksonen, A., Kulmala, M., Massoli, P., Onasch, T. B., Donahue, N. M., Riipinen, I., Davidovits, P., Worsnop, D., Petäjä, T., and Virtanen, A.: Adsorptive uptake of water by semisolid secondary organic aerosols, Geophys. Res. Lett., 42, 3063-3068, 2015

Price, H. C., Mattsson, J., Zhang, Y., Bertram, A. K., Davies, J. F., Grayson, J. W., Martin, S. T-, O'Sullivan, D., Reid, J. P., Rickards, A. M. J., and Murray, B. J.: Water diffusion in atmospherically relevant $\alpha$-pinene secondary organic material, Chem. Sci., 6, 4876-4883, 2015.

Pruppacher, H. R. and Klett, J. D.: Microphysics of Clouds and Precipitation, Atmospheric and Oceanographic Sciences Library, Kluwer Academic Publishers, Dordrecht, the Netherlands, 1997.

Pummer, B. G., Bauer, H., Bernardi, J., Bleicher, S., and Grothe, H.: Suspendable macromolecules are responsible for ice nucleation activity of birch and conifer pollen, Atmos. Chem. Phys., 12, 2541-2550, doi:10.5194/acp-12-2541-2012, 2012.

Renbaum-Wolff, L., Grayson, J., Bateman, A. P., Kuwata, K., Sellier, M., Murray, B. J., Schilling, J. E., Martin, S. T., and Bertram, A. K.: Viscosity of $\alpha$-pinene secondary organic material and implications for particle growth and reactivity, P. Natl. Acad. Sci. USA, 110, 8014-8019, 2013.
Riccobono, F., Schobesberger, S., Scott, C. E., Dommen, J., Ortega, I. K., Rondo, L., Almeida, J., Amorim, A., Bianchi, F., Breitenlechner, M., David, A., Downard, A., Dunne, E. M., Duplissy, J., Ehrhart, S., Flagan, R. C., Franchin, A., Hansel, A., Junninen, H., Kajos, M., Keskinen, H., Kupc, A., Kürten, A., Kvashin, A. N., Laaksonen, A., Lehtipalo, K., Makhmutov, V., Mathot, S., Nieminen, T., Onnela, A., Petäjä, T., Praplan, A. P., Santos, F. D., Schallhart, S., Seinfeld, J. H., Sipilä, M., Spracklen, D. V., Stozhkov, Y., Stratmann, F., Tomé, A., Tsagkogeorgas, G., Vaattovaara, P., Viisanen, Y., Vrtala, A., Wagner, P. E., Weingartner, E., Wex, H., Wimmer, D., Carslaw, K. S., Curtius, J., Donahue, N. M., Kirkby, J., Kulmala, M., Worsnop, D. R., and Baltensperger, U.: Oxidation products of biogenic emissions contribute to nucleation of atmospheric particles, Science, 344, 717-721, 2014.

Rogers, D. C.: Development of a continuous flow thermal gradient diffusion chamber for ice nucleation studies, Atmos. Res., 22, 149-181, 1988.

Schill, G. P., De Haan, D. O., and Tolbert, M. A.: Heterogeneous ice nucleation on simulated secondary organic aerosol, Environ Sci. Technol., 48, 1675-1682, 2014.

Seinfeld, J. H. and Pandis, S. N.: Atmospheric Chemistry and Physics: From Air Pollution to Climate Change, 2nd Edn., John Wiley and Sons, Inc., Hoboken, New Jersey, USA, 2006.

Stetzer, O., Baschek, B., Lüönd, F., and Lohmann, U.: The Zurich Ice Nucleation Chamber (ZINC) - a new instrument to investigate atmospheric ice formation, Aerosol Sci. Tech., 42, 64-72, 2008.

Suni, T., Hakola, H., Bäck, J., Hurley, R., van Gorsel, E., Ruuskanen, T., Kulmala, M., Sogacheva, L., Leuning, R., Cleugh, H., and Keith, H.: Effect of vegetation on aerosol formation in SouthEast Australia, in: Nucleation and Atmospheric Aerosols, edited by: O’Dowd, C. D. and Wagner, P. E., Springer Netherlands, 1018-1022, 2007.

Virtanen, A., Joutsensaari, J., Koop, T., Kannosto, J., Ylipirilä, P., Leskinen, J., Mäkelä, J. M., Holopainen, J. K., Pöschl, U., Kulmala, M., Worsnop, D. R., and Laaksonen, A.: An amorphous solid state of biogenic secondary organic aerosol particles, Nature, 467, 824-827, 2010.

Wagner, R., Möhler, O., Saathoff, H., Schnaiter, M., Skrotzki, J., Leisner, T., Wilson, T. W., Malkin, T. L., and Murray, B. J.: Ice cloud processing of ultra-viscous/glassy aerosol particles leads to enhanced ice nucleation ability, Atmos. Chem. Phys., 12, 85898610, doi:10.5194/acp-12-8589-2012, 2012.

Wang, B., Lambe, A. T., Massoli, P., Onasch, T. B., Davidovitsh, P., Worsnop, D. R., and Knopf, D. A.: The deposition ice nucleation and immersion freezing potential of amorphous secondary organic aerosol: pathways for ice and mixedphase cloud formation, J. Geophys. Res.-Atmos., 117, D16209, doi:10.1029/2012JD018063, 2012.

Welti, A., Lüönd, F., Stetzer, O., and Lohmann, U.: Influence of particle size on the ice nucleating ability of mineral dusts, Atmos. Chem. Phys., 9, 6705-6715, doi:10.5194/acp-9-6705-2009, 2009.

Wilson, T. W., Murray, B. J., Wagner, R., Möhler, O., Saathoff, H., Schnaiter, M., Skrotzki, J., Price, H. C., Malkin, T. L., Dobbie, S., and Al-Jumur, S. M. R. K.: Glassy aerosols with a range of compositions nucleate ice heterogeneously at cirrus tempera- 
tures, Atmos. Chem. Phys., 12, 8611-8632, doi:10.5194/acp-128611-2012, 2012.

Wu, Z. J., Nowak, A., Poulain, L., Herrmann, H., and Wiedensohler, A.: Hygroscopic behavior of atmospherically relevant water-soluble carboxylic salts and their influence on the water uptake of ammonium sulfate, Atmos. Chem. Phys., 11, 1261712626, doi:10.5194/acp-11-12617-2011, 2011.

Yu, H., Kaufman, Y. J., Chin, M., Feingold, G., Remer, L. A., Anderson, T. L., Balkanski, Y., Bellouin, N., Boucher, O., Christopher, S., DeCola, P., Kahn, R., Koch, D., Loeb, N., Reddy, M. S., Schulz, M., Takemura, T., and Zhou, M.: A review of measurement-based assessments of the aerosol direct radiative effect and forcing, Atmos. Chem. Phys., 6, 613-666, doi:10.5194/acp-6-613-2006, 2006.
Zobrist, B., Marcolli, C., Pedernera, D. A., and Koop, T.: Do atmospheric aerosols form glasses?, Atmos. Chem. Phys., 8, 52215244, doi:10.5194/acp-8-5221-2008, 2008. 